\title{
In vivo precision of three HR-pQCT-derived finite element models of the distal radius and tibia in postmenopausal women
}

\author{
C. E. Kawalilak ${ }^{1 *}$, S. A. Kontulainen², M. A. Amini' , J. L. Lanovaz², W. P. Olszynski ${ }^{3}$ and J. D. Johnston ${ }^{1}$
}

\begin{abstract}
Background: The distal radius is the most common osteoporotic fracture site occurring in postmenopausal women. Finite element (FE) modeling is a non-invasive mathematical technique that can estimate bone strength using inputted geometry/micro-architecture and tissue material properties from computed tomographic images. Our first objective was to define and compare in vivo precision errors for three high-resolution peripheral quantitative computed tomography (HR-pQCT, XtremeCT; Scanco) based FE models of the distal radius and tibia in postmenopausal women. Our second objective was to assess the role of scan interval, scan quality, and common region on precision errors of outcomes for each FE model.
\end{abstract}

Methods: Models included: single-tissue model (STM), cortical-trabecular dual-tissue model (DTM), and one scaled model using imaged bone mineral density (E-BMD). Using HR-pQCT, we scanned the distal radius and tibia of 34 postmenopausal women ( $74 \pm 7$ years), at two time points. Primary outcomes included: tissue stiffness, apparent modulus, average von Mises stress, and failure load. Precision errors (root-mean-squared coefficient of variation, $C \%_{\mathrm{RMS}}$ ) were calculated. Multivariate ANOVA was used to compare the mean of individual CV\% among the 3 HR-pQCT-based FE models. Spearman correlations were used to characterize the associations between precision errors of all FE model outcomes and scan/time interval, scan quality, and common region. Significance was accepted at $P<0.05$.

Results: At the distal radius, CV\% ${ }_{\text {RMs }}$ precision errors were <9 \% (Range STM: 2.8-5.3 \%; DTM: 2.9-5.4 \%; E-BMD: 4.4-8.7\%). At the distal tibia, CV\%RMs precision errors were <6 \% (Range STM: 2.7-4.8 \%; DTM: 2.9-3. $8 \%$; E-BMD: 1.8-2.5\%). At the radius, Spearman correlations indicated associations between the common region and associated precision errors of the E-BMD-derived apparent modulus $(\rho=-0.392 ; P<0.001)$ and von Mises stress $(\rho=-0.297 ; P=0.007)$.

Conclusion: Results suggest that the STM and DTM are more precise for modeling apparent modulus, average von Mises stress, and failure load at the distal radius. Precision errors were comparable for all three models at the distal tibia. Results indicate that the noted differences in precision error at the distal radius were associated with the common scan region, illustrating the importance of participant repositioning within the cast and reference line placement in the scout view during the scanning process.

Keywords: Distal radius, Distal tibia, Finite element modeling, HR-pQCT, Precision

\footnotetext{
* Correspondence: chantal.kawalilak@usask.ca

${ }^{1}$ Department of Mechanical Engineering, College of Engineering, University

of Saskatchewan, 57 Campus Drive, Saskatoon, SK S7N 5A9, Canada

Full list of author information is available at the end of the article
} 


\section{Background}

Osteoporosis and related fractures are global public health concerns that currently affect 200 million people worldwide [1] and are a major cause of mortality, morbidity, chronic pain, and loss of independence [2]. Distal radius fractures are the most common fracture type in postmenopausal women in North America and Europe [3-6]. Importantly, individuals who have suffered a distal radius fracture have greater risk of future osteoporotic wrist, hip, and spine fractures [7-9]. Further, 50-60\% of fragility fractures occur in women who are classified as osteopenic using dual-energy x-ray absorptiometry (DXA)derived areal bone mineral density (aBMD) - the clinical gold standard for osteoporosis diagnosis [10-12]. Therefore, information regarding bone's mechanical properties (e.g., bone stiffness and strength) is important in complementing fracture risk assessment beyond aBMD.

Research has shown that factors other than mineral mass or aBMD influence bone strength, such as: bone size, geometry, micro-architecture, and material properties. For instance, Kazakia and colleagues [13] have shown that two individuals can have identical DXA-derived T-scores and aBMD values but have significantly different 3D density, geometry and micro-architecture outcomes. Bone geometry and micro-architecture from HR-pQCT scans as well as strength estimates from finite element (FE) modeling have been reported to differentiate between women who have sustained a fracture relative to their non-fracture counterparts $[14,15]$ and identify those at high risk of fracture $[16,17]$. FE modeling is an engineering technique that can be applied to non-invasively simulate mechanical testing of bone. Using bone geometry/micro-architecture and tissue material properties derived from computed tomographic (CT) images, FE modeling can estimate bone mechanical properties in vivo [18-20].

Currently, there are three main types of HR-pQCTbased FE models: 1) homogeneous single-tissue model (STM) which models the distal radius or tibia as being comprised of empty voids and bone tissue with the same material stiffness (i.e., elastic modulus, E) for both cortical and trabecular bone [18]; 2) homogeneous dualtissue model (DTM) which separates cortical and trabecular bone (as well as voids) using different E's for each bone tissue [21]; and 3) a scaled model which links imaged bone mineral density (BMD) with $\mathrm{E}$ for each voxel via density-modulus E-BMD relationships [20].

Validation studies, comparing FE modeling to mechanical testing using cadaveric forearms, demonstrated close correlations between experimental findings and FEderived bone failure load or ultimate stress (STM: $R^{2}=$ 0.66-0.94) $[18,22,23]$ and stiffness (STM: $R^{2}=0.97$; E-BMD: $R^{2}=0.98$ ) [20]. These promising results offer great potential for HR-pQCT-based FE assessments of wrist fracture risk in populations prone to osteoporotic fractures, such as postmenopausal women. While the validity of the STM and E-BMD models have been investigated, there is little known about the repeatability (or precision) of all three FE models (i.e., STM, DTM, and E-BMD).

In order to detect and monitor small changes in bone strength over time and assess intervention/treatment effects, high measurement precision is fundamental $[24,25]$. Other than the precision of the input parameters (i.e., density, geometry, and micro-architecture) and time period between repeat scans (scan interval) [26], factors that may affect precision at distal bone sites include: limb and reference line repositioning (quantified as scan common region) [27, 28], and the degree of movement artifact (scan quality) [28, 29]. To date, two precision studies report reproducibility for the STM model using cadaveric forearms [30] and young adults [31]. Cadaveric precision errors, reported as percent coefficient-of-variation (CV\%), were 2.9 and $2.6 \%$ for stiffness and failure load, respectively [30]. Short-term in vivo precision errors for women, reported as rootmean-squared coefficient-of-variation $\left(\mathrm{CV} \%_{\mathrm{RMS}}\right)$, were 1.4 and $3.2 \%$ for average von Mises stress at the radius and tibia, respectively [31]. Other commonly reported variables include apparent modulus, and percent load carried by the cortical and trabecular bone (for DTM) (Table 1) [16, 18, 20, 21, 23, 28, 30-40]; however, precision error for these outcomes is unknown. Further, it remains unknown whether outcomes of the commonly used FE models are comparably repeatable-especially in postmenopausal women, a population most in need of accurate and reliable bone strength estimates.

The first objective of our study was to define and compare in vivo precision errors across three currently used HR-pQCT-based FE models (STM, DTM, scaled E$\mathrm{BMD})$ at the distal radius and tibia in postmenopausal women. The second objective was to determine the associations among time between follow-up scans (scan interval), scan quality, and common region on precision errors of all primary outcomes for each of the three FE models for the radius and tibia.

\section{Methods}

\section{Participants}

Measurements were completed on a sample of 34 postmenopausal women (74 \pm 7 years) from the Saskatoon cohort of the Canadian Multi-centre Osteoporosis (CaMos) Study [41]. Postmenopausal status was assessed using a questionnaire [42]. Osteoporosis status was based on femoral neck (FN) T-scores obtained from the Saskatoon CaMos database; specifically, five women were osteoporotic, 20 osteopenic and nine had normal T-scores [2, 41]. Participants filled out a questionnaire regarding their medication use for 12 months prior to their baseline visit, 
Table 1 Current literature using HR-pQCT finite element (FE) modeling for uniaxial compression simulations in the older human bone; illustrating the type of FE model used, the elastic modulus (E) used in the model, the reported outcomes, and the sites measured per study. Literature is listed in chronological order by year

\begin{tabular}{|c|c|c|c|c|}
\hline Reference & FE Model $^{a}$ & Elastic modulus (E) & Outcomes reported & Site measured \\
\hline $\begin{array}{l}\text { Pistoia et al. Bone 2002; 30(6): } \\
\text { 842-848. }\end{array}$ & STM & $10 \mathrm{GPa}$ & 1. Failure Load (N) & Cadaver Radius \\
\hline $\begin{array}{l}\text { MacNeil et al. Med Eng and Phys } \\
\text { 2007; 29: 1096-1105. }\end{array}$ & STM & $10 \mathrm{GPa}$ & $\begin{array}{l}\text { 1. Reaction Load }(\mathrm{N}) \\
\text { 2. Strain Energy Density } \\
\text { 3. Average von Mises Stress (MPa) }\end{array}$ & $\begin{array}{l}\text { Cadaver Radius } \\
\text { (Cube Sample) }\end{array}$ \\
\hline $\begin{array}{l}\text { MacNeil et al. Med Eng and Phys } \\
\text { 2008; 30: 792-799. }\end{array}$ & STM & Calculated $^{c}$ & $\begin{array}{l}\text { 1. Elastic Modulus }\left(C V \%_{\text {RMS }}\right)^{b} \\
\text { 2. Reaction Force }\left(C V \%_{\text {RMS }}\right)^{b} \\
\text { 3. Average von Mises Stress }\left(C V \%_{\text {RMS }}\right)^{b} \\
\text { 4. Strain Energy Density }\left(C \%_{\text {RMS }}\right)^{b}\end{array}$ & $\begin{array}{l}\text { In vivo } \\
\text { Radius and Tibia }\end{array}$ \\
\hline $\begin{array}{l}\text { MacNeil et al. Bone 2008; } \\
\text { 42: 1203-1213. }\end{array}$ & $\begin{array}{l}\text { STM } \\
\text { E-BMD }\end{array}$ & $\begin{array}{l}6829 \mathrm{MPa} \\
\mathrm{E}_{\text {element }}=15004 \times(\mathrm{\rho} / 1200 \mathrm{mg} \\
\left.\mathrm{HA} / \mathrm{cm}^{3}\right)^{1.7}\end{array}$ & $\begin{array}{l}\text { 1. Apparent Bone Strength (Ultimate } \\
\text { Stress) (GPa) }\end{array}$ & $\begin{array}{l}\text { In vivo } \\
\text { Radius }\end{array}$ \\
\hline $\begin{array}{l}\text { Boutroy et al. JBMR 2008; } \\
\text { 23(3): 392-399. }\end{array}$ & DTM & $\begin{array}{l}\text { Cortical: } 20 \mathrm{GPa} \\
\text { Trabecular: } 17.5 \mathrm{GPa}\end{array}$ & $\begin{array}{l}\text { 1. Stiffness }(\mathrm{kN} / \mathrm{mm}) \\
\text { 2. \% Load Carried by Each Tissue }{ }^{\mathrm{d}} \\
\text { 3. Average von Mises Stress for each } \\
\text { Tissue }^{\mathrm{d}}(\mathrm{MPa})\end{array}$ & $\begin{array}{l}\text { In vivo } \\
\text { Radius and Tibia }\end{array}$ \\
\hline $\begin{array}{l}\text { Mueller et al. Bone 2009; } \\
\text { 44: 364-371. }\end{array}$ & STM & $10 \mathrm{GPa}$ & $\begin{array}{l}\text { 1. Strength }(\mathrm{N}) \\
\text { 2. Stiffness }(\mathrm{N} / \mathrm{mm})\end{array}$ & Cadaver Radius \\
\hline $\begin{array}{l}\text { Dalzell et al. Osteoporos Int 2009; } \\
\text { 20: } 1683-1694 .\end{array}$ & STM & $10 \mathrm{GPa}$ & $\begin{array}{l}\text { 1. Stiffness }(\mathrm{N} / \mathrm{mm}) \\
\text { 2. Failure Load }(\mathrm{N})\end{array}$ & $\begin{array}{l}\text { In vivo } \\
\text { Radius and Tibia }\end{array}$ \\
\hline $\begin{array}{l}\text { Varga et al. J Biomech 2009; } \\
\text { 42: 1726-1731. }\end{array}$ & DTM & $\begin{array}{l}\text { Cortical: } 16.5 \mathrm{GPa} \\
\text { Trabecular: } 2974.0 \mathrm{MPa}\end{array}$ & $\begin{array}{l}\text { 1. Failure Load (N) } \\
\text { 2. Stiffness }(\mathrm{N} / \mathrm{mm})\end{array}$ & Cadaver Radius \\
\hline $\begin{array}{l}\text { Burghardt et al. JBMR 2010; } \\
\text { 25(12): 2558-2571. }\end{array}$ & DTM & $\begin{array}{l}\text { Cortical: } 10 \mathrm{GPa} \\
\text { Trabecular: } 10 \mathrm{GPa}\end{array}$ & $\begin{array}{l}\text { 1. Stiffness }(\mathrm{N} / \mathrm{mm}) \\
\text { 2. Apparent Modulus }\left(\mathrm{N} / \mathrm{mm}^{2}\right) \\
\text { 3. Failure Load }(\mathrm{N}) \\
\text { 4. \% Load Carried by Cortex }\end{array}$ & $\begin{array}{l}\text { In vivo } \\
\text { Radius and Tibia }\end{array}$ \\
\hline $\begin{array}{l}\text { Vilayphiou et al. Bone 2010; } \\
\text { 46: 1030-1037. }\end{array}$ & DTM & $\begin{array}{l}\text { Cortical: } 20 \mathrm{GPa} \\
\text { Trabecular: } 17 \mathrm{GPa}\end{array}$ & $\begin{array}{l}\text { 1. Failure Load }(\mathrm{N}) \\
\text { 2. Stiffness }(\mathrm{kN} / \mathrm{mm}) \\
\text { 3. \% Load Carried by Each Tissue } \\
\text { 4. Average von Mises stress for each } \\
\text { Tissue }^{\mathrm{d}}(\mathrm{MPa})\end{array}$ & $\begin{array}{l}\text { In vivo } \\
\text { Radius and Tibia }\end{array}$ \\
\hline $\begin{array}{l}\text { Varga et al. Bone. 2010; 47: } \\
\text { 982-988. }\end{array}$ & STM & $15 \mathrm{GPa}$ & $\begin{array}{l}\text { 1. Stiffness (kN.mm) } \\
\text { 2. Failure Load (kN) }\end{array}$ & Cadaver Radius \\
\hline $\begin{array}{l}\text { Vilayphiou et al. JBMR 2011; } \\
\text { 26(5): 965-973. }\end{array}$ & DTM & $\begin{array}{l}\text { Cortical: } 20 \mathrm{GPa} \\
\text { Trabecular: } 17 \mathrm{GPa}\end{array}$ & $\begin{array}{l}\text { 1. Failure Load }(\mathrm{N}) \\
\text { 2. Stiffness }(\mathrm{kN} / \mathrm{mm}) \\
\text { 3. \% Load Carried by Each Tissue } \\
\text { 4. Average von Mises stress for each } \\
\text { Tissue }^{\mathrm{d}}(\mathrm{MPa})\end{array}$ & $\begin{array}{l}\text { In vivo } \\
\text { Radius and Tibia }\end{array}$ \\
\hline $\begin{array}{l}\text { Macdonald et al. JBMR 2011; } \\
\text { 26(1): 50-62. }\end{array}$ & STM & $6829 \mathrm{MPa}$ & $\begin{array}{l}\text { 1. Stiffness (N/mm) } \\
\text { 2. Apparent Bone Strength (Ultimate } \\
\text { Stress) (MPa) } \\
\text { 3. Failure Load (N) } \\
\text { 4. \% Strain Energy Carried by each Tissue }{ }^{d}\end{array}$ & $\begin{array}{l}\text { In vivo } \\
\text { Radius and Tibia }\end{array}$ \\
\hline $\begin{array}{l}\text { Varga et al. Biomech Model } \\
\text { Mecahnobiol 2011; 10: 431-444. }\end{array}$ & DTM & $\begin{array}{l}\text { Cortical: } 15 \mathrm{GPa} \\
\text { Trabecular: } 15 \mathrm{GPa}\end{array}$ & $\begin{array}{l}\text { 1. Stiffness }(\mathrm{kN} / \mathrm{mm}) \\
\text { 2. Failure Load }(\mathrm{kN}) \\
\text { 3. Apparent Modulus }\left(\mathrm{kN} / \mathrm{mm}^{2}\right) \\
\text { 4. \% Load Carried by each Tissue }\end{array}$ & $\begin{array}{l}\text { Cadaver } \\
\text { Radius }\end{array}$ \\
\hline $\begin{array}{l}\text { Rizzoli et al. Osteoporos Int 2012; } \\
\text { 23: 305-315. }\end{array}$ & $\begin{array}{l}\text { DTM } \\
\text { E-BMD }\end{array}$ & $\begin{array}{l}\text { Cortical: } 20 \mathrm{GPa} \\
\text { Trabecular: } 17 \mathrm{GPa} \\
\text { Eelement }=15004 \times(\mathrm{\rho} / 900 \mathrm{mg} \\
\left.\mathrm{HA} / \mathrm{cm}^{3}\right)^{1.1}\end{array}$ & $\begin{array}{l}\text { 1. Failure Load }(\mathrm{N}) \\
\text { 2. Stiffness }(\mathrm{kN} / \mathrm{mm}) \\
\text { 3. Average von Mises stress for each } \\
\text { Tissue }^{\mathrm{d}}(\mathrm{MPa})\end{array}$ & $\begin{array}{l}\text { In vivo } \\
\text { Radius and Tibia }\end{array}$ \\
\hline $\begin{array}{l}\text { Nishiyama et al. Osteoprosis Int } \\
\text { 2012; 24(5): 1733-1740 }\end{array}$ & STM & $6829 \mathrm{MPa}$ & $\begin{array}{l}\text { 1. Apparent Bone Strength (Ultimate } \\
\text { Stress) (MPa) } \\
\text { 2. \% Load Carried by each Tissue }\end{array}$ & $\begin{array}{l}\text { In vivo } \\
\text { Radius and Tibia }\end{array}$ \\
\hline
\end{tabular}


Table 1 Current literature using HR-pQCT finite element (FE) modeling for uniaxial compression simulations in the older human bone; illustrating the type of FE model used, the elastic modulus (E) used in the model, the reported outcomes, and the sites measured per study. Literature is listed in chronological order by year (Continued)

\begin{tabular}{|c|c|c|c|c|}
\hline $\begin{array}{l}\text { Ellouz et al. Bone 2014; } \\
\text { 63: 147-157 }\end{array}$ & DTM & $\begin{array}{l}\text { Cortical: } 20 \mathrm{GPa} \\
\text { Trabecular: } 17 \mathrm{GPa}\end{array}$ & $\begin{array}{l}\text { 1. Stiffness }(\mathrm{kN} / \mathrm{mm}) \\
\text { 2. Average von Mises stress (MPa) for Each Tissue } \\
\text { 3. \% Load Carried by each Tissue }\end{array}$ & $\begin{array}{l}\text { In vivo } \\
\text { Radius and Tibia }\end{array}$ \\
\hline
\end{tabular}

${ }^{a}$ STM single tissue model, DTM dual tissue model, E-BMD scaled model based on bone mineral density

${ }^{b}$ Results of this study only report long-term and short-term precision errors (CV\%), outcome values not reported

'Elastic modulus (E) was calculated in this study based on the reaction force required to induce $1 \%$ strain over the average area of the slices within the section

d"Each tissue" refers separately to the cortical and trabecular tissues

where we recorded anti-osteoporosis medications (i.e., hormone replacement therapy and bisphosphonates) [43]. Of our participants in this precision study, no participants were using hormone replacement therapy and two participants were on bisphosphonates. Participant consent was attained prior to the study. This study was approved by the University of Saskatchewan Biomedical Research Ethics Board.

\section{HR-pQCT imaging}

Repeat measurements were performed with an average 10 days (SD 4 days) between baseline and follow-up. As per standard protocol, all participants had their nondominant arm and ipsilateral leg immobilized in the manufacturer-provided cast during scanning [41]. At the distal radius and tibia, a standard $9.02 \mathrm{~mm}$ region of interest (110 parallel CT slices) was obtained using HR-pQCT (XtremeCT; Scanco Medical AG, Brüttisellen, Switzerland) with an isotropic voxel size of $82 \mu \mathrm{m}$ [43]. The region of interest was located $9.5 \mathrm{~mm}$ (radius) and $22.5 \mathrm{~mm}$ (tibia) proximal from the reference line placement which was positioned from the mid-region of the radial endplate and the tibial plafond, respectively [41]. The scan time was $<2.8 \mathrm{~min}$ and the effective dose was $<4 \mu$ Sv per scan [43].

\section{HR-pQCT image analysis}

One investigator (CEK) scanned, graded, and analyzed all HR-pQCT images. All images were graded for quality according to the manufacturer's 5-point scale [41, 44]. Five radius and two tibia images with a quality of 4 or 5 were excluded from the study. In total, 27 radii and 32 tibiae were included in this current investigation and had scan qualities between 1 and 3 .

Image analysis was completed according to the manufacturer's standard evaluation and dual-threshold evaluation protocols (Scanco Module 64-bit IPL V5.08b). Briefly, standard image evaluation was used to define the periosteal surface of the radius and tibia using a semi-automatic edge-finding algorithm in a slice-by-slice manner, as described elsewhere [41, 43]. Modification of the periosteal contour line was done when it deviated from the outer bone surface. Once the standard evaluation was completed, the dualthreshold method was performed to separately define the cortical and trabecular bone tissues at both skeletal sites [45]. For the dual-threshold technique, the periosteal contour was imported from the standard evaluation image files and the endocortical contour was automatically created using a series of morphological operations (i.e., dilation and erosion) to separate the trabecular and cortical regions [45]. Modification of the endocortical contour line was done when it deviated from the endocortical surface, as previously described [46]. To separate bone from all other voxels (i.e., void, marrow, etc.), a fixed global threshold (400 $\mathrm{mg} \mathrm{HA} / \mathrm{cm}^{3}$ ) was applied automatically by the software during image processing.

\section{Finite Element (FE) modeling}

All three FE models (STM, DTM, E-BMD) had linearelastic, isotropic material properties. They were generated and solved using the Image Processing Language (IPL; version 1.15) software provided by Scanco Medical. FE models were created by converting every voxel in the scanned volume of interest (VOI) into 8node brick elements $[19,47]$. Image voxels in the VOI were converted to $\sim 2.6$ million elements at the radius and $\sim 4$ million elements at the tibia. Young's moduli (E) and Poisson's ratio are specified below. Boundary conditions were set to simulate a "high-friction" axial compression test with $1 \%$ axial compressive strain applied to the distal surface of the bone. The highfriction nature of the simulation resulted in suppression of nodal displacement in the $x$ and $y$ directions at the distal surface and all directions at the proximal surface.

\section{Single Tissue Model (STM)}

The STM is a discrete homogeneous model where all the bone voxels are assigned a single user-defined $\mathrm{E}$, in this case the standard E $=10 \mathrm{GPa}$ with Poisson's ratio = $0.3[18,19]$. Segmentation, with manual contour correction, took $\sim 30 \mathrm{~min}$ per radius or tibia. Using the 
standard Scanco workstation, the STM solved in $\sim 3 \mathrm{~h}$ per radius model and $\sim 5 \mathrm{~h}$ per tibia model.

\section{Dual Tissue Model (DTM)}

The DTM is a discrete model with cortical- and trabecular-specific E-values of $20 \mathrm{GPa}$ and $17 \mathrm{GPa}$, respectively [21, 33]. Poisson's ratio was set to 0.3 [19]. Segmentation, with manual contour correction, took $\leq 3 \mathrm{~h}$ per radius image and $\leq 5 \mathrm{~h}$ per tibia. Using the standard Scanco workstation, the DTM solved in $\sim 3 \mathrm{~h}$ per radius model and $\sim 5 \mathrm{~h}$ per tibia model.

\section{Density-based (E-BMD) model}

The density-based E-BMD model is a scaled model where the $\mathrm{E}$ of each element was derived from the grayvalue of the corresponding voxel in the image [20,48], using density-modulus Eq. (1) proposed by MacNeil and Boyd [20]:

$$
E=15,004\left(\frac{\rho}{1200}\right)^{1.7}
$$

Where $\rho$ is the density associated with each voxel. With this equation, individual $\mathrm{E}(\mathrm{MPa})$ are scaled in relation to fully mineralized bone $\left(1200 \mathrm{mg} \mathrm{HA} / \mathrm{cm}^{3}\right)$ and the coefficients in Eq. (1) have been derived from experimental testing [20]. Poisson's ratio was set to 0.3 [19]. The scaled E-BMD model solved in $\sim 5 \mathrm{~h}$ per radius model and $\sim 10 \mathrm{~h}$ per tibia model using the standard Scanco workstation.

The four primary outcomes for each model included: bone stiffness $(\mathrm{kN} / \mathrm{mm})$, calculated as the average reaction force at the distal surface divided by the applied displacement $(0.0902 \mathrm{~mm}$, corresponding to $1 \%$ strain with a $9.02 \mathrm{~mm}$ thick region); apparent modulus (MPa), calculated as the average reaction force at the distal surface divided by estimated cross-sectional area and a fixed known strain (1\%); average von Mises stress (MPa); and failure load $(\mathrm{kN})$, defined using the criterion developed by Pistoia et al. [18]. With this approach, fracture was assumed to occur when $2 \%$ of the bone tissue exceeded a critical energy equivalent strain limit of $7000 \mu \varepsilon$. For DTM, a critical energy equivalent strain limit of $3500 \mu \varepsilon$ was used because $\mathrm{E}$ for cortical bone $(\mathrm{E}=20 \mathrm{GPa})$ was twice that used with Pistoia's model $(E=10 \mathrm{GPa})$ [21]. We chose these four primary outcomes because they are the most commonly reported in the literature (Table 1) and common to all three FE models. Secondary outcomes included: the proportion of von Mises stress and the percentage of the ultimate failure load carried by the cortex and trabecular bone tissues (DTM only).

\section{Statistical analysis}

We assessed the precision error of each outcome for all FE models by calculating root-mean-squared coefficients of variation $\left(\mathrm{CV} \%_{\mathrm{RMS}}\right)[24,41]$.

$$
C V \%_{R M S}=\sqrt{\sum_{j=1}^{m}\left(\frac{\left(\frac{S D_{j}}{\bar{x}_{j}} \times 100 \%\right)^{2}}{m}\right)}
$$

where $S D_{j}$ was the sample standard deviation between the two measurements, $x_{j}$ was the mean of the two measurements, and $m$ was the number of participants in the analysis [24].

We determined the distribution of our dataset by calculating the skewness Z-score for all variables. The variables with skewness z-scores greater than 1.96 had a non-parametric distribution and were normalized using square root transformation. For Objective 1, we compared individual transformed $\mathrm{CV} \%$ across the three FE models using multivariate analysis of variance (MANOVA) followed by pairwise comparison. MANOVA models were adjusted for multiple comparisons using Bonferroni correction. For Objective 2, we performed Spearman correlations $(\rho)$ to determine the factors associated with the time between followup scans (scan interval), scan quality, and common region on precision errors of all outcomes for each of the three FE models for the radius and tibia. Significance was set to $P<0.05$. All statistical analyses were performed using IBM SPSS commercial statistics software (PASW, Version 23 for Windows, SPSS Inc., Chicago, IL, USA).

\section{Results}

For each of the three FE models, mean $( \pm \mathrm{SD})$ for outcome variables and $\mathrm{CV} \%_{\mathrm{RMS}}$ precision are summarized in Table 2 for the distal radius and in Table 3 for the distal tibia. For the primary outcomes at the distal radius, $\mathrm{CV} \%_{\mathrm{RMS}}$ precision for all models were $<9 \%$ (Range STM: 2.8-5.3 \%; DTM: 2.9-5.4 \%; E-BMD: 4.4-8.7 \%). At the distal tibia, CV\% ${ }_{\text {RMS }}$ precision for all models were $<6$ \% (Range STM: 2.7-4.8 \%; DTM: 2.9-3.8 \%; E-BMD: $1.8-2.5 \%)$.

At the radius, precision errors for the main outcomes across all three FE models were different from one another $(P<0.003)$. Precision error for apparent modulus was $3.4 \%$ higher for the E-BMD model compared to STM $(P=0.015)$, and $3.3 \%$ higher for the E-BMD model compared to the DTM $(P=0.018)$ (Fig. 1, Table 2). Compared to STM and DTM, the scaled E-BMD model provided $3.3 \%$ higher precision error for average von Mises stress $(P<0.001)$ (Fig. 1, Table 2). Precision error for the failure load was $2.2 \%$ higher for the E-BMD model compared to STM $(P=0.010)$, and $2.1 \%$ 
Table 2 Mean $( \pm S D)$ of the baseline and follow-up scans, mean $( \pm S D)$ of both measurements, root-mean-square precision error (CV\% $\left.\%_{\text {RMs }}\right)$ for stiffness, apparent stiffness, average von Mises stress, and failure load from 3 different FE models at the distal radius in postmenopausal women

\begin{tabular}{|c|c|c|c|c|c|c|c|c|}
\hline Radius $(n=27)$ & & First scan & $\pm S D$ & Second scan & $\pm \mathrm{SD}$ & Mean & $\pm S D$ & CV\% $\%_{\text {RMS }}$ \\
\hline \multicolumn{9}{|l|}{ Single Tissue Model (STM) } \\
\hline Stiffness & $(\mathrm{kN} / \mathrm{mm})$ & 57.2 & \pm 11.7 & 56.1 & \pm 11.7 & 56.6 & \pm 11.7 & 3.4 \\
\hline Apparent Modulus & $(\mathrm{MPa})$ & 1296.3 & \pm 340.2 & 1257.1 & \pm 307.7 & 1276.7 & \pm 320.6 & 5.3 \\
\hline Average von Mises Stress & $(\mathrm{MPa})$ & 58.0 & \pm 6.1 & 57.0 & \pm 5.9 & 57.5 & \pm 5.8 & 3.8 \\
\hline Failure Load & $(k N)$ & 2.944 & \pm 0.542 & 2.886 & \pm 0.543 & 2.915 & \pm 0.540 & 2.8 \\
\hline \multicolumn{9}{|l|}{ Dual Tissue Model (DTM) } \\
\hline Stiffness & $(\mathrm{kN} / \mathrm{mm})$ & 106.8 & \pm 22.3 & 105.2 & \pm 22.3 & 106.0 & \pm 22.2 & 3.3 \\
\hline Apparent Modulus & $(\mathrm{MPa})$ & 2428.5 & \pm 652.3 & 2355.2 & \pm 583.90 & 2391.9 & \pm 611.6 & 5.4 \\
\hline Average von Mises Stress & $(\mathrm{MPa})$ & 108.1 & \pm 12.2 & 106.2 & \pm 11.5 & 107.2 & \pm 11.5 & 3.8 \\
\hline Failure Load & $(k N)$ & 2.535 & \pm 0.488 & 2.505 & \pm 0.489 & 2.520 & \pm 0.486 & 2.9 \\
\hline \multicolumn{9}{|l|}{ Cortical Bone } \\
\hline Average von Mises Stress & $(\mathrm{MPa})$ & 153.5 & \pm 7.9 & 152.2 & \pm 7.4 & 152.8 & \pm 7.5 & 1.5 \\
\hline \% Minimum Load Carried & (\%) & 48.3 & \pm 8.4 & 48.4 & \pm 7.7 & 48.3 & \pm 7.8 & 6.1 \\
\hline$\%$ Maximum Load Carried & (\%) & 77.6 & \pm 9.0 & 77.8 & \pm 8.9 & 77.7 & \pm 8.8 & 2.2 \\
\hline \multicolumn{9}{|l|}{ Trabecular Bone } \\
\hline Average von Mises Stress & $(\mathrm{MPa})$ & 76.6 & \pm 12.1 & 74.4 & \pm 11.9 & 75.5 & \pm 11.4 & 6.7 \\
\hline \% Minimum Load Carried & (\%) & 51.8 & \pm 8.4 & 51.6 & \pm 7.7 & 51.7 & \pm 7.8 & 7.1 \\
\hline$\%$ Maximum Load Carried & (\%) & 22.4 & \pm 9.0 & 22.2 & \pm 8.9 & 22.3 & \pm 8.8 & 9.5 \\
\hline \multicolumn{9}{|l|}{ Scaled E-BMD Model } \\
\hline Stiffness & $(\mathrm{kN} / \mathrm{mm})$ & 41.1 & \pm 12.6 & 40.6 & \pm 12.0 & 40.8 & \pm 12.2 & 4.4 \\
\hline Apparent Modulus & $(\mathrm{MPa})$ & 595.2 & \pm 215.1 & 583.7 & \pm 184.1 & 589.4 & \pm 196.0 & 8.7 \\
\hline Average von Mises Stress & $(\mathrm{MPa})$ & 13.2 & \pm 4.0 & 13.0 & \pm 3.4 & 13.1 & \pm 3.6 & 7.1 \\
\hline Failure Load & $(k N)$ & 1.222 & \pm 0.373 & 1.194 & \pm 0.347 & 1.208 & \pm 0.357 & 5.0 \\
\hline
\end{tabular}

higher for the E-BMD model compared to the DTM $(P=0.025)$ (Fig. 1, Table 2). At the distal tibia, the precision for the main outcomes across all three FE models were not different from one another $(P=0.156)$ (Fig. 2, Table 3).

There were no associations regarding the scan interval and precision errors of main FE outcomes for any of the models at the radius and tibia $(P>0.05)$. Similarly, there were no associations between scan quality and precision errors of main FE outcomes for any of the models at the radius and tibia $(P>0.05)$. The only associations were for the E-BMD model between the common scan region and the precision of apparent modulus $(\rho=-0.392 ; P<$ $0.001)$ and von Mises stress $(\rho=-0.297 ; P=0.007)$ at the distal radius, but not the tibia $(P>0.05)$.

The common region for the distal radius was, on average, $93 \%$ (range: $81-99 \%$ ), while at the distal tibia, the common region was $97 \%$ (range: 88-99 \%) [41]. Further, at the distal radius, there was an average slice shift of -0.8 (Range: -19.1 to 16.8 slices), whereas at the distal tibia, the average slice shift was 1.8 (Range: -6.2 to 12.8 slices).

\section{Discussion}

The first objective of our study was to define and compare in vivo precision errors for three commonly used HR-pQCT-based FE models (two homogeneous and one scaled) at the distal radius and tibia in postmenopausal women. Precision error was significantly higher for apparent modulus, average von Mises stress, and failure load using the scaled E-BMD at the distal radius. At the distal tibia, however, all models had comparable outcomes. Reported in vivo precision errors at the radius for STM and DTM, but not E-BMD, were comparable to those reported in cadaveric forearms (CV\%: Failure Load: $2.6 \%$, Stiffness: $2.9 \%$ [30]) as well as previous in vivo precision at the radius in women $\left(\mathrm{CV} \%_{\mathrm{RMS}}\right.$ : Average von Mises stress: $1.4 \%$ [31]). Our in vivo precision error at the tibia for average von Mises stress for all models was comparable to those previously reported in women (CV\% ${ }_{\text {RMS }}: 3.2 \%$, [31]).

The second objective of our study was to determine the associations regarding scan quality, and common region on precision errors of all outcomes for each of 
Table 3 Mean $( \pm S D)$ of the baseline and follow-up scans, mean $( \pm S D)$ of both measurements, root-mean-square precision error $\left(\mathrm{CV} \%_{\mathrm{RMS}}\right)$ for stiffness, apparent stiffness, average von Mises stress, and failure load from 3 different FE models at the distal tibia in postmenopausal women

\begin{tabular}{|c|c|c|c|c|c|c|c|c|}
\hline Tibia $(n=32)$ & & First scan & $\pm S D$ & Second scan & $\pm \mathrm{SD}$ & Mean & $\pm S D$ & CV\% $\%_{\text {RMS }}$ \\
\hline \multicolumn{9}{|l|}{ Single Tissue Model (STM) } \\
\hline Stiffness & $(\mathrm{kN} / \mathrm{mm})$ & 172.7 & \pm 33.7 & 173.1 & \pm 34.1 & 172.9 & \pm 33.7 & 3.7 \\
\hline Apparent Modulus & $(\mathrm{MPa})$ & 1896.8 & \pm 375.2 & 1908.3 & \pm 374.3 & 1902.5 & \pm 372.0 & 4.0 \\
\hline Average von Mises Stress & $(\mathrm{MPa})$ & 66.6 & \pm 5.8 & 66.8 & \pm 5.4 & 66.7 & \pm 5.1 & 4.8 \\
\hline Failure Load & $(k N)$ & 8.746 & \pm 1.570 & 8.761 & \pm 1.587 & 8.754 & \pm 1.571 & 2.7 \\
\hline \multicolumn{9}{|l|}{ Dual Tissue Model (DTM) } \\
\hline Stiffness & $(\mathrm{kN} / \mathrm{mm})$ & 316.1 & \pm 60.9 & 317.2 & \pm 61.8 & 316.6 & \pm 61.0 & 3.4 \\
\hline Apparent Modulus & $(\mathrm{MPa})$ & 3477.5 & \pm 685.3 & 3500.6 & \pm 685.3 & 3489.1 & \pm 680.7 & 3.8 \\
\hline Average von Mises Stress & $(\mathrm{MPa})$ & 120.6 & \pm 10.2 & 120.9 & \pm 9.4 & 120.7 & \pm 9.3 & 3.8 \\
\hline Failure Load & $(k N)$ & 7.256 & \pm 1.345 & 7.267 & \pm 1.360 & 7.261 & \pm 1.345 & 2.9 \\
\hline \multicolumn{9}{|l|}{ Cortical Bone } \\
\hline Average von Mises Stress & $(\mathrm{MPa})$ & 166.4 & \pm 5.4 & 166.6 & \pm 5.6 & 166.5 & \pm 5.5 & 0.8 \\
\hline \% Minimum Load Carried & (\%) & 41.5 & \pm 9.1 & 41.9 & \pm 9.7 & 41.7 & \pm 9.4 & 3.5 \\
\hline$\%$ Maximum Load Carried & (\%) & 61.6 & \pm 9.9 & 61.8 & \pm 10.2 & 61.7 & \pm 10.0 & 2.1 \\
\hline \multicolumn{9}{|l|}{ Trabecular Bone } \\
\hline Average von Mises Stress & $(\mathrm{MPa})$ & 97.9 & \pm 11.6 & 97.8 & \pm 11.4 & 97.9 & \pm 10.8 & 5.9 \\
\hline$\%$ Minimum Load Carried & (\%) & 58.5 & \pm 9.1 & 58.2 & \pm 9.7 & 58.3 & \pm 9.4 & 2.6 \\
\hline \% Maximum Load Carried & (\%) & 38.4 & \pm 9.9 & 38.2 & \pm 10.2 & 38.3 & \pm 10.0 & 3.5 \\
\hline \multicolumn{9}{|l|}{ Scaled E-BMD Model } \\
\hline Stiffness & $(\mathrm{kN} / \mathrm{mm})$ & 118.7 & \pm 27.8 & 118.7 & \pm 27.5 & 118.8 & \pm 27.6 & 2.1 \\
\hline Apparent Modulus & $(\mathrm{MPa})$ & 910.6 & \pm 223.7 & 912.8 & \pm 224.9 & 911.7 & \pm 224.0 & 1.8 \\
\hline Average von Mises Stress & $(\mathrm{MPa})$ & 16.7 & \pm 3.3 & 16.8 & \pm 3.2 & 16.7 & \pm 3.2 & 2.0 \\
\hline Failure Load & $(k N)$ & 3.558 & \pm 0.802 & 3.556 & \pm 0.797 & 3.557 & \pm 0.797 & 2.5 \\
\hline
\end{tabular}

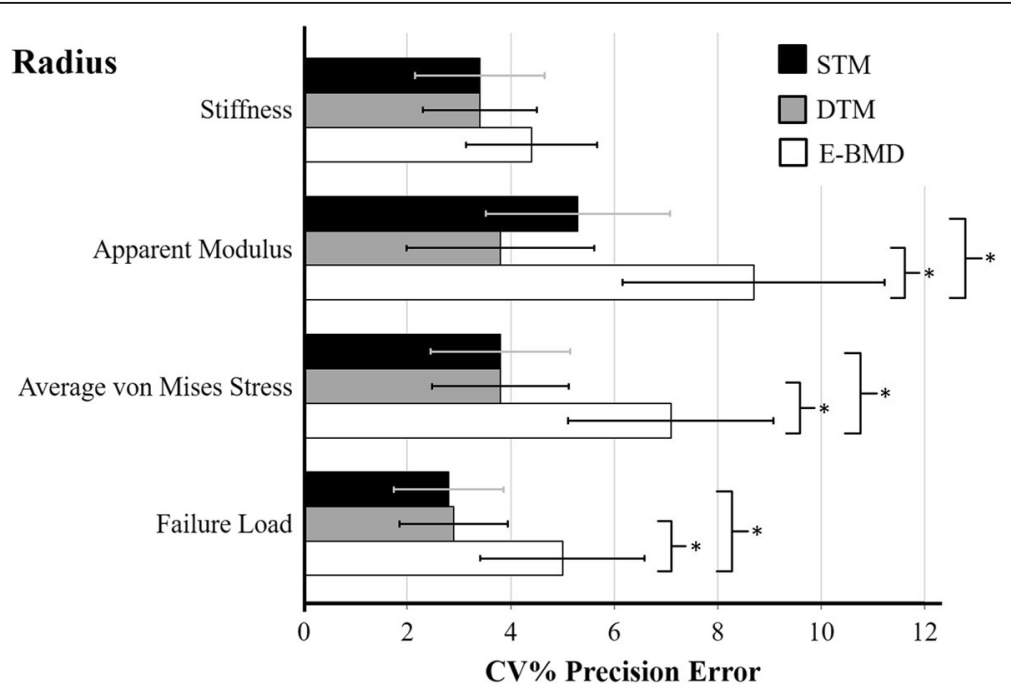

Fig. 1 Comparison of root-mean-square precision errors (CV\% $\%_{\text {RMS }}$ ) and $95 \%$ confidence intervals for tissue stiffness, apparent modulus, average von Mises stress, and failure load in postmenopausal women at the distal radius. * Significant at $P<0.05$ 


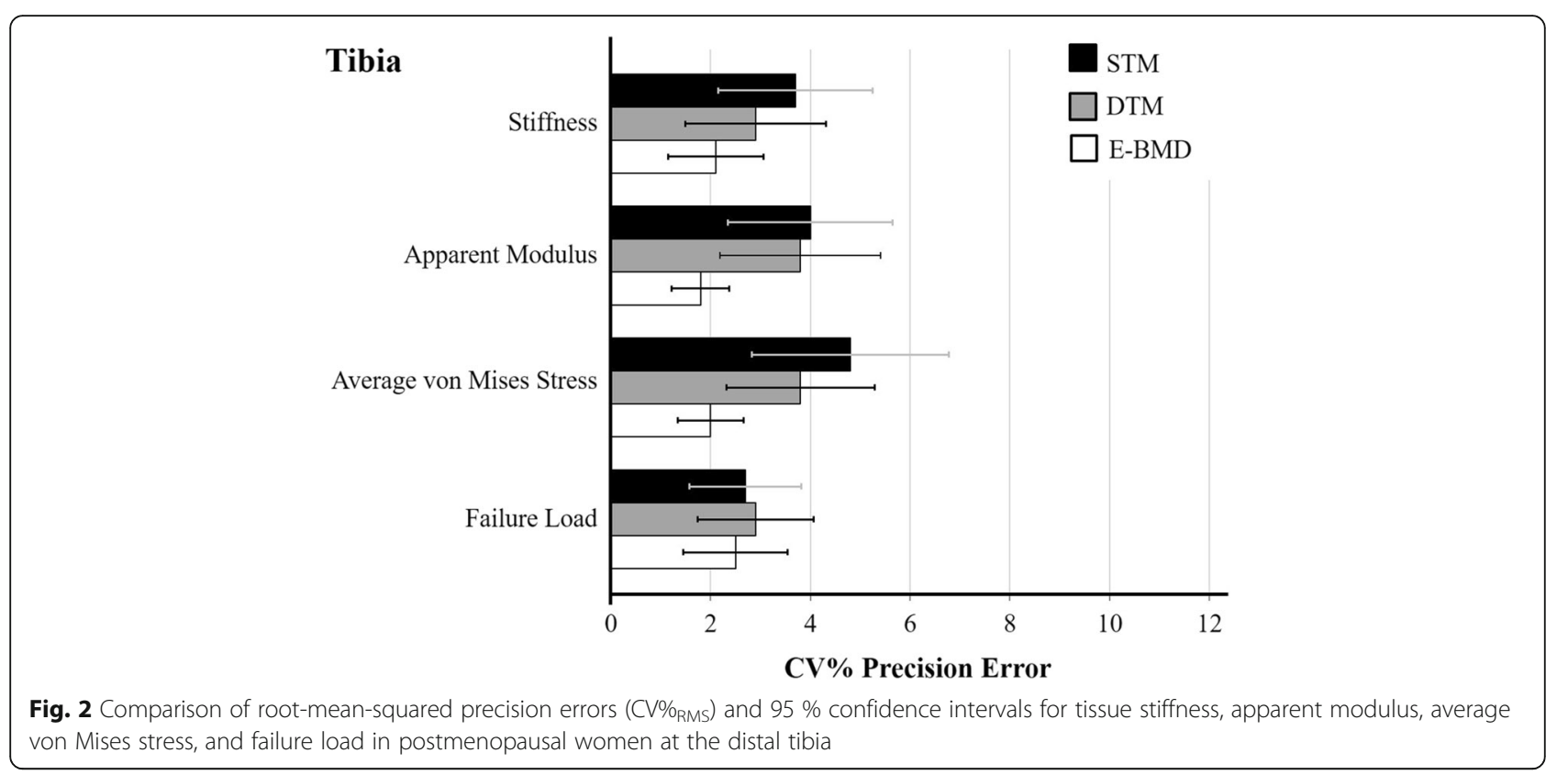

the three FE models for the radius and tibia. Results indicated that the noted differences in precision errors at the radius were significantly associated with the common scan region. It is likely that this relationship was not apparent at the tibia because of the similar common regions between the repeated measurements at this site. Previous research has suggested that even small rotation angles can lead to considerable variance in the scan region [28]. While the use of the cross-sectional area registration method within the HR-pQCT software aids in the correction of axial misplacement between baseline and follow-up scans, it does not account for possible 3D misalignments in the limb within the cast [28]. The arm cast allows for the possibility of more rotation at the wrist, while it was easier to consistently place the leg within the leg cast. The compounded effect of reference line inconsistencies between successive scans also affects the common region. This illustrates the importance of repositioning (both the limb in the cast and the reference line on the scout view).

While not an objective of the study, the actual model outcomes merit some discussion. The failure load was similar among the STM and DTM as a direct reflection of the failure criteria and boundary conditions (i.e., STM: $2 \%$ of the bone is strained to greater than or equal to $7000 \mu \varepsilon$ with an E of $\sim 10 \mathrm{GPa}$; DTM: $2 \%$ of the bone is strained to greater than or equal to $3500 \mu \varepsilon$ with an $\mathrm{E}$ of $\sim 20 \mathrm{GPa})$. However, the failure load for the EBMD model was approximately half the failure load defined by the STM and DTM at both sites. This was primarily because, due to the density-scaled nature on how $\mathrm{E}$ was assigned, the final E-BMD model consisted of a large number of elements with low $\mathrm{E}$ and high strain, thus a lower failure load. This concept is similar to the DTM adjustment where the strain limit was lowered from 7000 to $3500 \mu \varepsilon$ to account for increasing the E from $10 \mathrm{GPa}$ to $20 \mathrm{GPa}$. Without this critical strain limit adjustment, the failure load with DTM would be twice that with STM. For this case, the opposite is true (i.e., with a critical strain limit of $7000 \mu \varepsilon$ and E lower than $10 \mathrm{GPa}$, the failure load is lower than STM or DTM). These results indicate a higher critical strain limit is needed when estimating failure load with EBMD-a criterion that will require validation using experimental testing. Connected to this point, it is interesting to note that Pistoia's original model used to develop the failure load criterion employed STM with a single E equal to $10 \mathrm{GPa}$. Because a single $\mathrm{E}$ was assigned to all bone elements, a critical energy equivalent strain limit of $7000 \mu \varepsilon$ or a critical energy equivalent stress limit of $70 \mathrm{MPa}$ would give identical failure loads. As such, the criterion could have been established according to stress instead of strain. In fact, when we ran the failure analysis using energy equivalent stress, failure loads with E-BMD were comparable to those with STM and DTM (results not reported). This was because the stress analysis focused on elements with high $\mathrm{E}$, not low $\mathrm{E}$. These results indicate that energy equivalent stress is an appropriate metric for estimating failure loads with HR-pQCT-based FE modeling; though, this needs to be confirmed using experimental validation testing. In addition to differences in failure load, there also appeared to be differences in: stiffness, apparent modulus, and von Mises stress among the three models at both sites. Specifically, stiffness, apparent modulus and von 
Mises stress with DTM were approximately double the values relative to both the STM and E-BMD. These outcomes reflect the higher user-defined E with DTM (DTM: $\mathrm{E}=20 \mathrm{GPa}$ for cortical bone; STM $=10 \mathrm{GPa}$ for all bone; $\mathrm{E}-\mathrm{BMD} \approx 15 \mathrm{GPa}$ for cortical bone scaled to $1200 \mathrm{mg} \mathrm{HA} /$ $\mathrm{cm}^{3}$ ). The stiffness and apparent modulus for the E-BMD model appeared lower relative to the STM. This was also due to the density-scaled nature of the E-BMD model which resulted in a limited number of bone elements with high $\mathrm{E}(15 \mathrm{GPa})$ and a larger number with low $\mathrm{E}$; whereas, with STM all bone elements had E $=10 \mathrm{GPa}$. Specifically, in the E-BMD model the elements include void and bone in the same voxel-this will lower the density of the material within the voxel and thereby lower the apparent modulus of the element (and the stiffness of the bone). This is in contrast to the STM and DTM models that binarize the bone into two materials-bone or void-and therefore all the bone elements in the model will increase the stiffness and apparent modulus similarly between the STM and DTM. MacNeil and Boyd [20] noted that usage of $E=$ $6.829 \mathrm{GPa}$ with the STM instead of E = $10 \mathrm{GPa}$ gave comparable outcomes between the STM and the E-BMD model applied in this study. We elected to use $\mathrm{E}=10 \mathrm{GPa}$ for the STM as it is the most commonly applied approach for HR-pQCT-based FE modeling of the distal radius and tibia. When applying E $=6.829 \mathrm{GPa}$ with the STM (results not reported), stiffness outcomes were closer between the models (e.g., STM stiffness: $117.9 \mathrm{kN} / \mathrm{mm}$; E-BMD stiffness: 118.7 $\mathrm{kN} / \mathrm{mm}$ ). The average von Mises stress was also lower for the E-BMD model relative to the STM and DTM. This may reflect the fact the scaled E-BMD model does not use thresholding, which has been noted to increase the partial volume effect as well as the bone area and results in a lower stress [20]. Partial volume effects may also result in less stiff elements (i.e., lower E) and a less stiff overall structure, resulting in a lower average von Mises stress.

Other than accuracy and precision, additional factors to consider when deciding what model to use include: computational time, analysis time and assumptions used within the models' (e.g., user-defined E). The STM has the shortest total analysis time (i.e., image segmentation and FE analysis) per model for both the radius (3.5 h) and tibia $(5.5 \mathrm{~h})$. Overall, the DTM and the E-BMD models have approximately equal analysis times at both sites (radius: $5 \mathrm{~h}$; tibia: $9-10 \mathrm{~h}$ ) because of the time commitment for dual thresholding of the cortex for the DTM. However, the E-BMD model does not require invested manual time in the segmentation part of the analysis because it uses the unsegmented files so the majority of the analysis time comes from the complex FE modeling. According to Burghardt et al. [39], the use of binarized models (i.e., STM and DTM) will facilitate understanding pertaining to how bone micro-architecture changes in response to treatment or intervention and the mechanics of bone strength. However, using the STM or DTM will not provide information regarding how changes in bone mineral affect bone strength [39] (bone mineral mass being an important factor underpinning bone strength [49]), an advantage of the E-BMD model. Therefore, depending on the research question as well as balancing precision, computational time, costs associated with analysis/segmentation, and the assumptions used within the models, either the STM or scaled E-BMD model may be the favorable model to implement in future research.

Our study design and study cohort had strengths that warrant consideration. First, repeat measurements were separated by an average of 1 week-an important condition because underestimation of precision error has been reported when precision is calculated using scans repeated on the same day [26]. Second, our study contained enough repeat scans $(N \geq 27)$ to provide the recommended 27 degrees of freedom necessary to establish reliable precision errors with an upper $90 \%$ confidence limit less than $30 \%$ (e.g., if the precision error was $2 \%$, then we were $90 \%$ confident that the true precision error is less than $2.6 \%$ ) $[24,50]$. Third, the reported bone health status of our sample of postmenopausal women was comparable to their peers in North America, Europe, Australia and Japan $[10,41,51]$, thereby suggesting our data is generalizable to postmenopausal women in these regions.

Limitations associated with this study pertain to our study sample population and sample size. First, although we studied older postmenopausal women, skeletal precision may vary according to duration or time from menopause and osteoporosis status which was not considered in this study-this merits further investigation into populationspecific precision studies. A second limitation pertained to our sample size. While our sample size was sufficient to obtain the required degrees of freedom for accurate precision error estimates, it was limited to assess the possible role of osteoporosis or bone status as well as the influence of FE input parameters (i.e., density, geometry, and microarchitecture) in the comparisons.

Future studies in this area should include further investigations into the factors that affect precision error and metrics for monitoring change for each FE model. The scan quality in our study was very homogeneous and thereby did not affect the precision of our FE models; consequently, this restricted our ability to fully address the impact of these factors on precision error. Previous work has shown that poor scan quality corresponds to significantly higher precision error in outcomes [44]. Considering the densitometric, geometric, and micro-architectural information from HR-pQCT are used as input parameters for our FE models it is logical poor precision in these outcomes could lead to poor precision of FE outcomes. Future research, with a larger sample size, is needed to address this question. Further, future studies should investigate the 
extent to which each model can detect change in bone strength metrics and what time interval between follow-up scans are required to capture these changes.

\section{Conclusions}

In summary, all methods provided similar precision for modeling the distal tibia, whereas the STM and DTM appeared more precise for modeling the distal radius. However, considering precision, computational time, costs associated with analysis/segmentation, and model assumptions, the scaled E-BMD model may be the favorable model to implement in future research. Noted differences in precision error at the distal radius were associated with the common scan region between follow-up measures. Study results illustrate the importance of appropriate participant (re)positioning within the cast and reference line placement in the scout view during the scanning process.

\section{Abbreviations \\ aBMD: Areal bone mineral density; CT: Computed tomography; CV\%: Coefficient of variation (in percent); CV\% ${ }_{\text {RMs: }}$ Root-means-squared coefficient of variation (in percent); DTM: Dual tissue model; DXA: Dual- energy x-ray absorptiometry; E-BMD: A scaled finite element model which links imaged bone mineral density (BMD) with Young's Modulus (E) for each voxel via density-modulus E-BMD relationships; FE: Finite element; FN: Femoral neck; GPa: Giga pascals; HA: Hydroxyapatite; HR-pQCT: High-resolution peripheral quantitative computed tomography; MANOVA: Multivariate analysis of variance; MPa: Megapascals; STM: Single tissue model; VOl: Volume of interest; $\mu \varepsilon$ : Microstrain; $\rho$ : Density}

\section{Acknowledgements}

We would like to thank all our CaMos Saskatoon cohort participants for their continued altruism and volunteering for scientific research. We thank Dr. Andrew Frank-Wilson and Jola Thingvold for coordinating the study measurements. We also acknowledge Nicolas Vilayphiou and Scanco Medical for their help in troubleshooting. We also extend thanks to Dr. Martin Nilsson for his suggestion to investigate image quality. Authors also acknowledge the University of Saskatchewan, Saskatchewan Health and Research Foundation (SHRF), and the Canadian Institutes of Health Research (CIHR) for their funding support. This work was supported in part by grants from CIHR Regional Partnership Program New Investigator Award, a CIHR Operating Grant (MOP98002), the Canadian Foundation for Innovation (CFI 16935), and a SHRF Establishment Grant (2632).

\section{Funding}

Authors also acknowledge the University of Saskatchewan, Saskatchewan Health and Research Foundation (SHRF), and the Canadian Institutes of Health Research (CIHR) for their funding support. This work was supported in part by grants from CIHR Regional Partnership Program New Investigator Award, a CIHR Operating Grant (MOP98002), the Canadian Foundation for Innovation (CFI 16935), and a SHRF Establishment Grant (2632). The funding sources had no role in: study design, data collection, data analysis, data interpretation, and writing the manuscript.

\section{Availability of data and materials}

Our ethics agreement prevents us from making our data publically available. However, data may be available upon request and institutional approval.

\section{Authors' contributions}

CK co-developed study design and research protocol together with SK, JDJ and JL. WO facilitated participant recruitment. CK performed all HR-pQCT measurements, image analyses, and statistical analyses. CK, SK, JDJ and JL together interpreted the data. CK and MA programmed the finite element (FE) models into the XtremeCT FE solver. CK drafted the manuscript and revised versions based on the critical feedback from SK, JDJ, MA, JL, and
WO. All authors (CK, SK, JDJ, MA, JL, and WO) approve the final version of this manuscript for publication.

\section{Competing interests}

Chantal E Kawalilak, Saija A Kontulainen, Morteza A Amini, Joel L Lanovaz, Wojciech Olszynski, and James D Johnston declare that they have no conflict of interest or competing interests.

\section{Consent for publication}

Not Applicable (our manuscript does not contain any individual person's data).

\section{Ethics approval and consent to participate}

Participant consent was attained prior to the study. This study was approved by the University of Saskatchewan Biomedical Research Ethics Board.

\section{Author details}

'Department of Mechanical Engineering, College of Engineering, University of Saskatchewan, 57 Campus Drive, Saskatoon, SK S7N 5A9, Canada. ${ }^{2}$ College of Kinesiology, University of Saskatchewan, Saskatoon, Canada. ${ }^{3}$ College of Medicine, University of Saskatchewan, Saskatoon, Canada.

Received: 22 December 2015 Accepted: 31 August 2016

Published online: 13 September 2016

\section{References}

1. Leslie WD, Morin SN. Osteoporosis epidemiology 2013: implications for diagnosis, risk assessment, and treatment. Curr Opin Rheumatol. 2014;26(4):440-6.

2. Papaioannou A, Morin S, Cheung AM, Atkinson S, Brown JP, Feldman S, et al. 2010 clinical practice guidelines for the diagnosis and management of osteoporosis in Canada: summary. Can Med Assoc J. 2010;182(17):1864-73.

3. Mueller TL, van Lenthe GH, Stauber M, Gratzke C, Eckstein F, Muller R. Regional, age and gender differences in architectural measures of bone quality and their correlation to bone mechanical competence in the human radius of an elderly population. Bone. 2009;45(5):882-91.

4. Spadaro JA, Werner FW, Brenner RA, Fortino MD, Fay LA, Edwards WT. Cortical and trabecular bone contribute strength to the osteopenic distal radius. J Orthop Res. 1994;12(2):211-8

5. Alffram P-A, Bauer GCH. Epidemiology of fractures of the forearm: a biomechanical investigation of bone strength. J Bone Joint Surg. 1962; 44A(1):105-14.

6. Owen RA, Melton Jr L, Johnson KA, Ilstrup DM, Riggs BL. Incidence of Colles' fracture in a North American community. Am J Public Health. 1982;72(6):605-7.

7. Mallmin H, Ljunghall S, Persson I, Naessen T, Krusemo U-B, Bergstrom R. Fracture of the distal forearm as a forecaster of subsequent hip fracture: a population-based cohort study with 24 years follow-up. Calcif Tissue Int. 1993;52:269-72.

8. Gaerdsell P, Johnell O, Nilsson BE, Gullberg B. Predicting various fragility fractures in women by forearm bone densitometry: a follow-up study. Calcif Tissue Int. 1993;52:348-53.

9. Cuddihy MT, Gabriel SE, Crowson CS, O'Fallon WM, Melton 3rd L. Forearm fractures as predictors of subsequent osteoporotic fractures. Osteoporos Int 1999:9:469-75.

10. Kanis JA. Diagnosis of osteoporosis and assessment of fracture risk. Lancet. 2002:359:1929-36

11. Siris ES, Miller PD, Barrett-Connor E, Faulkner KG, Wehren LE, Abbott TA, et al. Identificantion and fracture outcomes of undiagnosed low bone mineral density in postmenopausal women: results from the national osteoporosis risk assessment. J Am Med Assoc. 2001:286(22):2815-22.

12. Cranney A, Jamal SA, Tsang JF, Josse RG, Leslie WD. Low bone mineral density and fracture burden in postmenopausal women. CMAJ. 2007;177(6):575-80.

13. Kazakia GJ, Burghardt AJ, Link TM, Majumdar S. Variations in morphological and biomechanical indices at the distal radius in subjects with identical BMD. J Biomech. 2011:44(2):257-66.

14. Sornay-Rendu E, Boutroy S, Munoz F, Bouxsein ML. Cortical and trabecular architecture are altered in postmenopausal women with fractures. Osteoporos Int. 2009;20(8):1291-7.

15. Sornay-Rendu E, Boutroy S, Munoz F, Delmas PD. Alterations of cortical and trabecular architecture are associated with fractures in postmenopausal women, partially independent of decreased BMD measured by DXA: the OFELY study. J Bone Miner Res. 2007;22(3):425-33. 
16. Boutroy S, Van Rietbergen B, Sornay-Rendu E, Munoz F, Bouxsein ML, Delmas PD. Finite element analysis based on in vivo HR-pQCT images of the distal radius is associated with wrist fracture in postmenopausal women. J Bone Miner Res. 2008;23(3):392-9.

17. Amin S, Kopperdhal DL, Melton 3rd L, Achenbach SJ, Therneau TM, Riggs $\mathrm{BL}$, et al. Association of hip strength estimates by finite-element analysis with fractures in women and men. J Bone Miner Res. 2011;26(7):1593-600.

18. Pistoia W, van Rietbergen B, Lochmuller EM, Lill CA, Eckstein F, Ruegsegger $P$. Estimation of distal radius failure load with micro-finite element analysis models based on three-dimensional peripheral quantitative computed tomography images. Bone. 2002;30(6):842-8.

19. Medical S. Scanco Medical finite element software. Version 1.13 ed. Bruetisellen: SCANCO Medical Ag Fabrikweg 2 CH-8306; 2009.

20. MacNeil JA, Boyd SK. Bone strength at the distal radius can be estimated from high-resolution peripheral quantitative computed tomography and the finite element method. Bone. 2008;42(6):1203-13.

21. Vilayphiou N, Boutroy S, Sornay-Rendu E, Van Rietbergen B, Munoz F, Delmas PD, et al. Finite element analysis performed on radius and tibia HR-pQCT images and fragility fractures at all sites in postmenopausal women. Bone. 2010;46(4):1030-7.

22. Pistoia W, van Rietbergen B, Lochmüller EM, Lill CA, Eckstein F, Rüegsegger P. Image-based micro-finite-element modeling for improved distal radius strength diagnosis. J Clin Densitom. 2004;7(2):153-60.

23. Varga P, Dall'Ara E, Pahr DH, Pretterklieber M, Zysset PK. Validation of an HR-pQCT-based homogenized finite element approach using mechanical testing of ultra-distal radius sections. Biomech Model Mechanobiol. 2011:10(4):431-44.

24. Glüer CC, Blake G, Lu Y, Blunt BA, Jergas M, Genant HK. Accurate assessment of precision errors: how to measure the reproducibility of bone densitometry techniques. Osteoporos Int. 1995;5:262-70.

25. Glüer CC. Monitoring skeletal changes by radiological techniques. J Bone Miner Res. 1999;14(11):1952-62.

26. Swinford RR, Warden SJ. Factors affecting short-term precision of musculoskeletal measures using peripheral quantitative computed tomography (pQCT). Osteoporos Int. 2010;21(11):1863-70.

27. Bonnick SL, Johnston CC, Kleerekoper M, Lindsay R, Miller P, Sherwood L, et al. Importance of precision in bone density measurements. J Clin Densitom. 2001; 4(2):105-10.

28. Ellouz R, Chapurlat $R$, van Rietbergen B, Christen P, Pialat JB, Boutroy S Challenges in longitudinal measurements with HR-pQCT: evaluation of a $3 \mathrm{D}$ registration method to improve bone microarchitecture and strength measurement reproducibility. Bone. 2014:63:147-57.

29. Pauchard Y, Liphardt AM, Macdonald HM, Hanley DA, Boyd SK. Quality control for bone quality parameters affected by subject motion in high-resolution peripheral quantitative computed tomography. Bone. 2012;50(6):1304-10.

30. Mueller TL, Stauber M, Kohler T, Eckstein F, Muller R, van Lenthe GH. Noninvasive bone competence analysis by high-resolution $\mathrm{PQCT}$ : an in vitro reproducibility study on structural and mechanical properties at the human radius. Bone. 2009:44(2):364-71.

31. MacNeil JA, Boyd SK. Improved reproducibility of high-resolution peripheral quantitative computed tomography for measurement of bone quality. Med Eng Phys. 2008;30(6):792-9.

32. MacNeil JA, Boyd SK. Load distribution and the predictive power of morphological indices in the distal radius and tibia by high resolution peripheral quantitative computed tomography. Bone. 2007:41(1):129-37.

33. Vilayphiou N, Boutroy S, Szulc P, van Rietbergen B, Munoz F, Delmas PD, et al. Finite element analysis performed on radius and tibia HR-pQCT images and fragility fractures at all sites in men. J Bone Miner Res. 2011;26(5):965-73.

34. Macdonald HM, Nishiyama KK, Kang J, Hanley DA, Boyd SK. Age-related patterns of trabecular and cortical bone loss differ between sexes and skeletal sites: a population-based HR-pQCT study. J Bone Miner Res. 2011;26(1):50-62.

35. Rizzoli R, Chapurlat RD, Laroche JM, Krieg MA, Thomas T, Frieling I, et al. Effects of strontium ranelate and alendronate on bone microstructure in women with osteoporosis. Results of a 2-year study. Osteoporos Int. 2012;23(1):305-15.

36. Nishiyama KK, Macdonald HM, Hanley DA, Boyd SK. Women with previous fragility fractures can be classified based on bone microarchitecture and finite element analysis measured with HR-pQCT. Osteoporos Int. 2012;24(5):1733-40.

37. Dalzell N, Kaptoge S, Morris N, Berthier A, Koller B, Braak L, et al. Bone micro-architecture and determinants of strength in the radius and tibia: age-related changes in a population-based study of normal adults measured with high-resolution pQCT. Osteoporos Int. 2009:20(10):1683-94.

38. Varga P, Baumbach S, Pahr D, Zysset PK. Validation of an anatomy specific finite element model of Colles' fracture. J Biomech. 2009:42(11):1726-31.

39. Burghardt AJ, Kazakia GJ, Sode M, de Papp AE, Link TM, Majumdar S. A longitudinal HR-pQCT study of alendronate treatment in postmenopausal women with low bone density: Relations among density, cortical and trabecular microarchitecture, biomechanics, and bone turnover. J Bone Miner Res. 2010:25(12):2558-71.

40. Varga P, Pahr DH, Baumbach S, Zysset PK. HR-pQCT based FE analysis of the most distal radius section provides an improved prediction of Colles' fracture load in vitro. Bone. 2010;47(5):982-8.

41. Kawalilak CE, Johnston JD, Olszynski WP, Leswick D, Kontulainen SA. Comparison of short term in vivo precision of bone density and microarchitecture at the distal radius and tibia between postmenopausal women and young adults. J Clin Densitom. 2014;17(4):510-7.

42. Kreiger N, Tenehouse A, Joseph L, Mackenzie T, Poliquin S, Brown JP, et al. The Canadian multicentre osteoporosis study (CaMos): background, rationale, methods. Can J Aging. 1999;18(3):376-87.

43. Kawalilak CE, Johnston JD, Olszynski WP, Kontulainen SA. Characterizing micro-architectural changes at the distal radius and tibia in postmenopausal women using HR-pQCT. Osteoporos Int. 2014;25(8):2057-66.

44. Pialat JB, Burghardt AJ, Sode M, Link TM, Majumdar S. Visual grading of motion induced image degradation in high resolution peripheral computed tomography: impact of image quality on measures of bone density and micro-architecture. Bone. 2012;50(1):111-8.

45. Burghardt AJ, Buie HR, Laib A, Majumdar S, Boyd SK. Reproducibility of direct quantitative measures of cortical bone microarchitecture of the distal radius and tibia by HR-pQCT. Bone. 2010;47(3):519-28.

46. Kawalilak CE, Johnston JD, Cooper DML, Olszynski WP, Kontulainen SA. Role of endocortical contouring methods on precision of HR-pQCT-derived cortical micro-architecture in postmenopausal women and young adults. Osteoporos Int. 2015: Accepted Manuscript.

47. van Rietbergen B, Weinans $H$, Huiskes $R$, Odgaard A. A new method to determine trabecular bone elastic properties and loading using micromechanical finite-element models. J Biomech. 1995;28(1):69-81.

48. Homminga J, Huiskes $R$, van Rietbergen $B$, Ruegsegger $P$, Weinans $H$. Introduction and evaluation of a gray-value voxel conversion technique. J Biomech. 2001;34:513-7.

49. Ammann P, Rizzoli R. Bone strength and its determinants. Osteoporos Int. 2003;14 Suppl 3:S13-8.

50. Engelke K, Adams JE, Armbrecht G, Augat P, Bogado CE, Bouxsein ML, et al. Clinical use of quantitative computed tomography and peripheral quantitative computed tomography in the management of osteoporosis in adults: the 2007 ISCD Official Positions. J Clin Densitom. 2008;11(1):123-62.

51. Kanis JA, McCloskey EV, Johansson H, Oden A, Melton 3rd LJ, Khaltaev N. A reference standard for the description of osteoporosis. Bone. 2008:42(3):467-75.

\section{Submit your next manuscript to BioMed Central and we will help you at every step:}

- We accept pre-submission inquiries

- Our selector tool helps you to find the most relevant journal

- We provide round the clock customer support

- Convenient online submission

- Thorough peer review

- Inclusion in PubMed and all major indexing services

- Maximum visibility for your research

Submit your manuscript at www.biomedcentral.com/submit 